DOI: $10.19195 / 0137-1134.110 .1$

\title{
POLITYCZNOŚĆ NAUKI PRAWA I PRAKTYKI PRAWNICZEJ — WPROWADZENIE
}

Prezentowane artykuły są inspirowane obradami XXII Zjazdu Katedr Teorii i Filozofii Prawa, który odbył się we Wrocławiu w dniach 18-21 września 2016 roku. Część opracowań przygotowana została przez osoby, które na zaproszenie organizatorów wygłosiły referaty na dwóch sesjach plenarnych. Teksty prezentowane $\mathrm{w}$ tej części są zmodyfikowaną i uporządkowaną wersją wystąpień konferencyjnych. Tom zawiera również artykuły przygotowane przez innych uczestników Zjazdu. W ten sposób powstało opracowanie, które jakkolwiek ściśle, personalnie i problemowo związane jest z sesjami plenarnymi XXII Zjazdu Katedr Teorii i Filozofii Prawa, znacząco wykracza poza jej pierwotne ramy. Chcemy bardzo gorąco podziękować wszystkim autorom tekstów zamieszczonych w niniejszej publikacji za obecność i aktywność na ubiegłorocznej konferencji oraz za wysiłek wniesiony w ostateczny kształt prezentowanego wydawnictwa.

Zaproponowana w tytule Zjazdu problematyka została ujęta w postaci trójstronnej relacji: prawo - polityka - sfera publiczna. Propozycja miała skłaniać do dyskusji nad współczesną kondycją prawa i prawoznawstwa oraz uwarunkowaniami, jakie dla naszej dziedziny badawczej niosą jej coraz mocniejsze — przez jednych krytykowane, przez innych uznawane za nieuchronne — związki z polityką i życiem publicznym. Swobodną inspirację dla tytułowej triady pojęciowej zaczerpnęliśmy z metafory trzech zegarów, przedstawionej przez Ralfa Dahrendorfa ${ }^{1}$. Niemiecki socjolog, opisując zmiany społeczno-ustrojowe w Europie Środkowo-Wschodniej po roku 1989, użył metafory trzech zegarów: politycznego, ekonomicznego oraz społeczeństwa obywatelskiego. Zdaniem R. Dahrendorfa zegar polityczny bije najszybciej, ponieważ proces legislacyjny, co widzimy ostatnio w Polsce, przebiega bardzo szybko, stawiając pod znakiem zapytania stabilizacyjną funkcję prawa. Zadeklarowane zmiany polityczne dość łatwo, w krótkim horyzoncie czasowym, na poziomie normatywnym dają się wprowadzać do stanowionego porządku prawnego. Zegar ekonomiczny odmierza czas już znacznie wolniej, ponieważ wymaga zbudowania odpowiednich instytucji, które będą urzeczywistniały zadeklarowany w przepisach prawnych porządek. Instytucje te, choć

1 Zob. P. Sztompka, Kapitat Społeczny. Teoria przestrzeni międzyludzkiej, Kraków 2016, s. $13-14$. 
mają w sobie wymiar prawny, są jednak czymś znacznie bardziej złożonym aniżeli teksty prawne ustanowione przez politycznego prawodawcę. Wymagają aplikacji i odpowiedniego ugruntowania w określonej praktyce — zarówno prawniczej, jak i w innych obszarach życia społecznego. Ostatni zegar — społeczeństwa obywatelskiego — bije najwolniej, ponieważ odmierza tempo zmian moralności publicznej. W naszym przekonaniu przedstawioną metaforę można spożytkować do ukazania wzajemnych relacji między wyróżnionymi praktykami, tj. prawem, polityką oraz sferą publiczną, w odniesieniu do bardzo różnych doktrynalnych i filozoficznych idei i konceptów prawniczych. Przykładem może tu być choćby tak istotna i żywo obecnie w Polsce dyskutowana zasada rządów prawa. Można ją rozpatrywać nie tylko z punktu widzenia rozstrzygnięć prawodawczych, lecz także kondycji instytucji życia społecznego, a nawet całego społeczeństwa obywatelskiego.

Jak to się ostatnio dość często zdarza, zaproponowany z pewnym wyprzedzeniem czasowym (w 2014 roku) temat Zjazdu Katedr, na skutek przeobrażeń społecznych i prawno-ustrojowych obserwowanych w ostatnich kilkunastu miesiącach, zyskał na aktualności, a jednocześnie zmiany te mocno wyeksponowały jeden fragment zaproponowanej triady, tj. problem polityczności prawa i praktyki prawniczej. Dość powszechne stało się przekonanie, że jesteśmy świadkami kolejnego zakrętu, na którym znalazły się założenia demokracji liberalnej i opartej na niej idei rządów prawa. Jednym z efektów są coraz mocniej artykułowane głosy rekomendujące zerwanie z ideą apolityczności i zastąpienie jej twierdzeniem o potrzebie etycznego i politycznego zaangażowania działalności - nie tylko orzeczniczej, lecz także naukowej. Powoduje to również narastanie w środowisku teoretyków i filozofów prawa napięcia związanego z pytaniami o rozumienie i status pojęcia polityczności oraz o kryteria oceny polityczności prawa i prawoznawstwa. Kwalifikacje te są przedmiotem sporu między różnymi orientacjami metodologicznymi. W ich świetle polityczność rozumiana jest jako cecha ,przyrodzona" sferze prawa, działalności prawniczej albo właściwość nabyta na skutek podjętej aktywności. Najdalej idącym staje się jednak obecnie pytanie o to, czy racje polityczne mogą w naszej kulturze prawnej oraz przy aprobowanych dotychczas kryteriach naukowości kierować i uzasadniać zarówno postępowanie osób sprawujących władzę publiczną, w tym sądowniczą, jak i zawodową aktywność pracowników akademii.

Próbą zajęcia stanowiska wobec teoretycznie, filozoficznie, a także praktycznie trudnych wyzwań jest właśnie prezentowany tom. Bogatsi o dyskusję, która miała miejsce na ubiegłorocznym Zjeździe Katedr, postanowiliśmy prezentowanej monografii nadać nowy tytuł, a mianowicie Polityczność nauki prawa i praktyki prawniczej. Sądzimy, że nieco lepiej oddaje on rzeczywiste rezultaty naszego naukowego spotkania. Opracowanie zawiera teksty trzynastu autorów reprezentujących polskie ośrodki teorii i filozofii prawa. Jak zawsze w tego typu zbiorowych pracach bywa, są to artykuły zróżnicowane nie tylko problemowo, 
lecz także w zastosowanych podejściach badawczych i stylistykach pisarskich. Wewnętrzne usystematyzowanie takiej różnorodności w wydawniczą całość nie jest łatwe, gdyż niesie za sobą pewne, być może ryzykowne, interpretacje z naszej strony poglądów poszczególnych autorów, a niekiedy nawet może mieć cechy arbitralności. Pomni tych niebezpieczeństw postanowiliśmy zaproponować taką strukturę niniejszego tomu, która odwołuje się do trzech poziomów (a zarazem sposobów argumentacji i języków) debatowania o polityczności prawa i praktyki prawniczej, a mianowicie do dyskursów: 1) filozoficzno-prawnego na temat możliwych relacji, głównie aksjologicznych i pojęciowych, między prawem a polityką, 2) przedmiotowego, obejmującego racje pochodzące $\mathrm{z}$ obszaru tzw. konstytucjonalizmu oraz 3) praktycznego, obejmującego swym zakresem praktykę tworzenia i stosowania prawa.

Celem niniejszego tomu nie jest, i nie mogło być, ukazanie jednego, wewnętrznie spójnego pod względem metodologicznym i problemowym sposobu ujmowania kwestii z obszaru polityczności nauki prawa i praktyki prawniczej. Przeciwnie, chodziło raczej o konceptualizację podejmowanych obecnie w rodzimym środowisku teoretyków i filozofów prawa problemów w tym obszarze, o ekspozycję poszczególnych, w naszej ocenie reprezentatywnych dla tego środowiska stanowisk. Czasy, w których przyszło nam ostatnio funkcjonować zawodowo, nie sprzyjają dystansowi abstrakcji, łączonemu zazwyczaj z analitycznym myśleniem i argumentowaniem. Jest bowiem czas porządkowania i czas działania (tworzenia, niszczenia). Ideę inspirującą wydanie niniejszej książki, lepiej chyba niż dystans analityków, oddaje stwierdzenie Hegla o potrzebie takiego filozofowania, które polega na „uchwyceniu w myśli swojego czasu”. Czy środowisko polskich teoretyków i filozofów prawa ma zdolność odpowiadania na wyzwania „swojego czasu”? Ocenę wypada pozostawić czytelnikom. Mamy tylko nadzieję, że zamieszczone w niniejszym tomie teksty dostarczą materiał, który okaże się przydatny do takiej oceny.

Chcielibyśmy podziękować Panom Profesorom: Krzysztofowi Pałeckiemu oraz Marcinowi Matczakowi za sporządzenie recenzji wydawniczych. Opinie obu Panów Profesorów w istotny sposób wpłynęły na ostateczny kształt niniejszej publikacji, w jej wymiarze zarówno merytorycznym, jak i organizacyjnym. Dziękujemy również za życzliwość oraz wsparcie finansowe władzom Wydziału Prawa, Administracji i Ekonomii Uniwersytetu Wrocławskiego oraz Wojewódzkiego Sądu Administracyjnego we Wrocławiu. Współpraca z takimi osobami, jak Dziekani naszego Wydziału - Profesor Włodzimierz Gromski, Profesor Wiesława Miemiec, Profesor Karol Kiczka — oraz Prezes WSA mgr Ryszard Pęk, okazała się dla nas nieocenioną pomocą.

Andrzej Bator, Przemysław Kaczmarek

Wrocław, lipiec 2017 roku 